\title{
THE BUILDING
}

\section{BLOCKS OF BIOLOGY}

\author{
EVERYTHING IN BIOLOGY CAN BE REDUCED TO INDIVIDUAL \\ ATOMS. WORKING OUT HOW THESE ATOMS FORM MOLECULES, \\ HOW THEY INTERACT WITH ONE ANOTHER AND WHAT THIS MEANS \\ FOR BIOLOGICAL ORGANISMS IS THE FOCUS OF DR ANGELA \\ GRONENBORN'S WORK AT THE UNIVERSITY OF PITTSBURGH
}

\section{TALK LIKE A STRUGTURAL BIOLOGIST}

FLUORINE: A relatively light element that comes after oxygen in the periodic table. It is not often naturally present in organisms, particularly animals.

ISOTOPE: A variety of an element that has a different number of neutrons to protons. They may be written as (for example) carbon-13 or $13 \mathrm{C}$, where the number refers to the sum of the element's protons and neutrons.

\section{MACROMOLECULE: A molecule} containing a very large number of atoms, such as a protein or nucleic acid.

\section{NUCLEAR MAGNETIC RESONANCE} SPECTROSCOPY: A type of spectroscopy that involves putting molecules in a magnetic field and recording the signal produced by excitation of the sample.
NUCLEIC ACID: The biomolecules that make up organisms' genetic code, i.e. DNA.

PROTEIN: A biomolecule made of amino acids, that are coded for by nucleic acids.

SPECTROSCOPY: A technique that involves studying the interaction of molecules and electromagnetic radiation (e.g. radio waves).

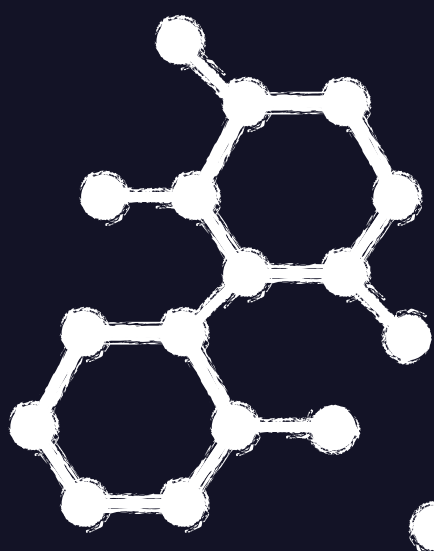

Uncovering the molecular interactions that govern biological cells is not straightforward. There are a range of techniques that structural biologists use to find out what is going on at the molecular level. Think of the analogy of the elephant and blindfolded people: each person can feel one part of the elephant - its trunk, its leg and so on - but only by communicating with one another can they get a sense of what the whole creature looks like. It's the same in structural biology: only through different teams of researchers, using different techniques and collaborating, can they get a sense of the bigger picture, and have an effective, positive impact on the world.

\section{NMR SPECTROSCOPY}

Dr Angela Gronenborn is an advocate of Nuclear Magnetic Resonance (NMR) Spectroscopy, a technique used to find out the structure of proteins and other molecules. Firstly, the target molecule is created with certain isotopes within its structure. Every isotope has its own magnetic identity and will vibrate at a certain frequency when exposed to a magnetic field. 
ANGELA'S TOP TIPS FOR STUDENTS

01 Create your own path. Don't try to follow in anyone's footsteps.

02 Become a well-rounded person. As well as science, explore the humanities, literature and languages.

03 There is nothing wrong with failing; in fact, failing fast is the best. Then you can regroup and try again!

\section{PATHWAY FROM SCHOOL TO STRUGTURAL BIOLOGIST}

Angela recommends taking mathematics, physics and chemistry at school. Biology can also be useful, but isn't always essential - Angela does not have a biological background herself. She also advises seeking a well-rounded education, featuring literature and languages if possible.

At university, courses such as biochemistry, molecular biology, biomedicine, and other similar subjects can all lead to a career in structural biology.

NMR involves placing these samples within a strong magnetic field and recording the excitation patterns that the isotopes involved give off. These 'resonance frequencies' are recorded and used to identify the structure of the molecule. Once this information is collected, it undergoes complex analysis using sophisticated computational tools. The end product is a three-dimensional model that can be visualised and explored on a computer screen.

\section{ISOTOPES AND FLUORINE}

Isotopes are formed when an atom has a different number of neutrons to protons, a property that gives them a unique signature while still retaining all the element's normal chemical properties. A common way to get isotopes into the target molecule is to grow bacteria on isotope-rich nutrients so that they are incorporated into their biomolecules, which are then extracted. Common isotopes used in NMR include deuterium (hydrogen-2), carbon-13 and nitrogen-15, because these are accessible isotopes of the elements that are most common within organisms.
However, Angela's research uses fluorine-19 rather than the more conventional isotopes. Fluorine is not found naturally within biomolecules. "The overall goal of this research programme is to establish fluorine-19 NMR spectroscopy as a versatile approach for describing the structure and geometry of proteins," she says.

The main advantage of using fluorine is that it rarely suffers from background interference. Because isotopes of hydrogen, carbon and nitrogen are commonly found in nature, they often show up in NMR even when they're not part of the target molecule. Adding fluorine-19 to a molecule means that, if its resonance frequency shows up in analysis, it's almost certainly within the target molecule. However, because it is not a natural part of most biology, the researchers must be vigilant when adding it to molecules. "Each protein behaves differently and we always have to make sure that the molecule's folding pattern or its stability is not influenced."

\section{REAL-WORLD APPLICATIONS}

"The project involves an integration of computational and experimental

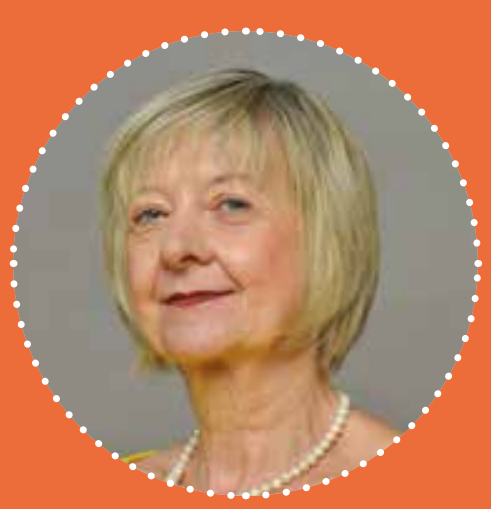

\section{OR ANGELA M GRONENBORN}

UPMC Rosalind Franklin Chair and Distinguished Professor, Department of Structural Biology, University of Pittsburgh, USA

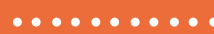

\section{FIELD OF RESEARCH}

Structural Biology

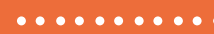

\section{RESEARCH PROJEGT}

Investigating the applications of fluorine NMR spectroscopy as a technique for understanding structural biology.

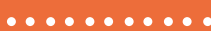

\section{FUNDERS}

National Institutes of Health National Science Foundation

approaches," says Angela. "We also plan to integrate scientific training with humanities, to help prepare students for communicating science to the public." The team hopes to demonstrate the usefulness of fluorine NMR as a technique to uncover important information that other techniques cannot.

Angela's team has already made headway using fluorine NMR to decipher proteins and small pharmaceutical molecules. This has some important practical applications. "We will use fluorine NMR to perform drug screenings, which should be very useful for drug design," she says. Angela hopes to use the technique on live cells, to be able to see what proteins are doing in real time.

The team has also found some unexpected effects, in particular regarding molecules' fluorescence properties - in other words, the radiation they emit. "There are always surprises," says Angela. "That is what's nice about science - there is always a new puzzle to solve." 


\section{ABOUT STRUCTURAL BIOLOGY}

WHAT IS STRUCTURAL BIOLOGY?

Structural biology is the study of the molecular structure and interactions of biological macromolecules. In particular, it focuses on proteins and nucleic acids, which are responsible for the majority of complex and fundamental functions within cells. It's a field that incorporates aspects of molecular biology, biochemistry and biophysics.

\section{LET'S ASK ANGELA:}

\section{WHAT DO YOU FIND MOST} REWARDING ABOUT YOUR WORK?

"Every day there is a new puzzle," says Angela. "No two problems are alike and every time it's a case of working progressively towards the most likely explanation. This involves a lot of deduction: testing all possible explanations, and discarding them if they don't hold up, until you come across the one most likely to be true."

\begin{abstract}
WHAT PERSONAL QUALITY DO YOU FIND MOST USEFUL FOR YOUR RESEARCH?

"I am very lucky in that I have a very good visual memory," says Angela. "So, once I have seen a protein model, I know what it looks like. Looking at a protein on a screen, turning it around and picking out every detail - it gets ingrained in my mind."

\section{WHY IS AN INTEGRATED, COLLABORATIVE APPROACH SO IMPORTANT?}

"Nature is complex and complexity needs to be addressed in its totality," says Angela. "With any method we use for viewing an object, we omit some of its features and only get a partial view. We need to integrate many such views to get closer to a more complete understanding. And, from a practical perspective, collaboration helps me do better science. We cannot be experts at everything, but by combining our areas of expertise, we can become unbeatable!"
\end{abstract}

\section{WHAT LARGE-SCALE PROJECT} WOULD YOU LIKE TO SEE BECOME REALITY?

"As structural biologists we would love to have a full 'movie' of a cell, and to see how it's affected by disease and other factors. We can then use our structural understanding to investigate the molecular pathways that have gone wrong, and work out solutions. That would be fantastic."

\section{WHAT DO YOU THINK IS}

\section{SCIENCE EDUCATION'S BIGGEST}

\section{CHALLENGE?}

"I believe all young children are naturally curious and could be attracted to science. Unfortunately, 'learning by doing' is a not a common approach in schools for teaching science, and this can mean basic scientific understanding is not attained by many. As scientists, we have to constantly try to educate those around us."

\section{HOW TO BECOME A STRUGTURAL BIOLOGIST}

- Structural biology is rarely an undergraduate course in itself, but its close cousins, molecular biology and

biochemistry, sometimes are. Relevant material is often covered within wider biology and chemistry courses, too.

- According to UK News, the best UK universities for courses involving molecular biology and genetics are Cambridge, Oxford, University College London, Edinburgh and Imperial College London.

- According to US News, the best US universities for courses involving molecular biology and genetics are Harvard, MIT, Stanford, California (San Francisco) and John Hopkins.

- According to Payscale.com, the average salary for a molecular biologist is $\$ 59 \mathrm{k}$.

\section{MEET SCIENTISTS WHO HAVE WORKED WITH ANGELA:}

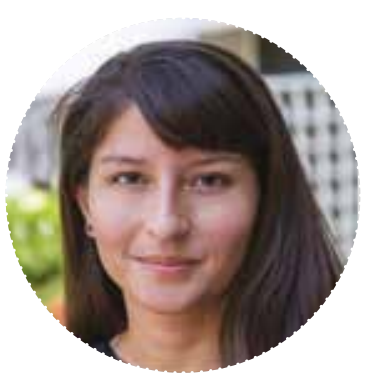

NAIMA SHARAF
WHAT LED YOU TO BECOME A SCIENTIST?

As a child I had lots of interests, including solving jigsaw puzzles with my dad. My love of puzzles translates well to the lab, where I am tackling scientific puzzles daily. In high school, I wanted to be a psychiatrist, but my mum strongly advised I go into science. I chose to study chemistry, which seemed like a good challenge. I instantly loved it! Without my mother's push, I wouldn't be in science today.

WHAT WAS YOUR ROLE ON THIS PROJECT?

I was the primary author with Dr Gronenborn on a number of papers on fluorine NMR. My role was to incorporate fluorine-modified amino acids into proteins. I was able to use this to label an enzyme that's a major target for HIV treatment, and then study its reactions to inhibitors that could go on to become pharmaceutical drugs.

\section{WHAT DID YOU FIND}

REWARDING ABOUT THE PROJECT?

I love fluorine NMR - the data were beautiful! It's free from 


\section{HOW DID DR ANGELA GRONENBORN BECOME A STRUCTURAL BIOLOGIST?}

\author{
WHERE DOES YOUR PASSION FOR \\ SCIENCE COME FROM? \\ I'm not exactly sure. At school, I \\ was convinced I was going to be a \\ mathematician, but the principal and my \\ father cautioned me that it would be a \\ difficult career as a woman. So, I decided I \\ would study physics and chemistry. The real \\ excitement came during my PhD when I \\ was exposed to the new field of molecular \\ biology by my biologist brother. I decided I \\ would ultimately use my training in NMR \\ to study biological systems, which was \\ impossible at that time.
}

\author{
HOW DO YOU OVERCOME

\section{OBSTACLES IN YOUR WORK?} \\ I am very stubborn and opinionated. I'll \\ try and try again, even if something seems \\ almost impossible. I become obsessed with \\ a problem and cannot let it go.

\section{WHAT DO YOU LIKE TO DO OUTSIDE OF WORK?} \\ I do not need to switch off, because I don't \\ see research as work. I am very fortunate \\ that I get paid for doing my hobby! There \\ are very few professions where one has such \\ a privilege - artists perhaps, but compared
}

to artists we get paid royally. However, I do enjoy art and music, and wherever I travel to give lectures, I make time to visit a museum.

\section{WHAT ARE YOUR GOALS FOR THE FUTURE? \\ I hope that I can help my students achieve what they want to achieve. I have been extremely lucky in my career and I want to empower those trainees within my sphere of influence to find their own luck.}

background signals and gives us lots of information about protein interactions.

\section{WHAT'S NEXT FOR YOUR CAREER?}

Next year, I will become a professor at one of two universities, along with my husband who's received similar offers from both. Now, we just have to decide which one!

\section{WHO INSPIRES YOUR} WORK?

My mum and Dr Gronenborn are great motivational figures. I am a mother of two young boys myself, and my mum acts as a role model for my work-life balance. Dr Gronenborn is a fantastic scientist as she works carefully and methodically, always making sure the data support the conclusions.
DO YOU HAVE ANY ADVICE FOR POTENTIAL FUTURE SCIENTISTS?

I would say go for it, and don't let people tell you what you can and cannot do!

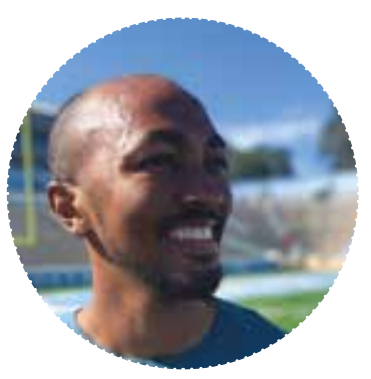

CHRIS BARNES

\section{WHAT LED YOU TO}

\section{BECOME A SCIENTIST?}

For a long time, I wanted to become a chef. I started cooking meals when I was 7 and really enjoyed the satisfaction of seeing people enjoy my food. In a way, being a chef encouraged me to be creative and 'experiment' with different recipes, which laid the groundwork for a scientific career.

\section{WHAT WAS YOUR ROLE IN} ANGELA'S DEPARTMENT?

When I was a graduate student, I worked on understanding transcription (the cellular process that makes proteins from amino acids). I explored the possibility of using fluorine NMR within a project, but it never moved out of the initial phase.

\section{WHAT'S NEXT FOR YOUR CAREER?}

I'm currently on the academic job market and am looking forward to starting my own lab at a leading research institution. I hope to research how to design drugs to target proteins involved in infectious disease. I hope that my future work will inspire the next generation of scientists, especially individuals of colour who may not feel like they belong in our field.

\section{WHO INSPIRES YOUR WORK?}

Broadly, Barack Obama is someone I admire and try to emulate. However, now I have children of my own, I find my parents are my main source of inspiration. Looking back, I now really appreciate how they provided me and my siblings with a great childhood.

\section{DO YOU HAVE ANY} ADVICE FOR POTENTIAL FUTURE SCIENTISTS?
I always make sure to let young scientists from underrepresented minorities know that they belong. Representation matters and by taking part in initiatives to diversify STEM, I hope I show young scientists what they can become. In my own early career, I never saw another face that looked like mine and often questioned whether I belonged - it's an isolating experience. I think it's important to let young scientists know that they are not alone and that their feelings are real. I always remind them to take pride in their accomplishments - they earned it, after all. 